УАK 342.4

ББК 67.400.2

DOI 10.22394/1682-2358-2018-5-56-62

O.I. Tsybulevskaya, Doctor of Sciences (Law), Professor, Head of the Theory of Law Department, Honorary Figure of Russian Higher Education, Povolzbsky Institute of Management named after P.A. Stolypin, Branch of the Russian Presidential Academy of National Economy and Public Administration

T.V. Milusheva, Doctor of Sciences (Law), Head of the Civil Law and Proceedings Department, Povolzhsky Institute of Management named after P.A. Stolypin, Branch of the Russian Presidential Academy of National Economy and Public Administration

\section{THE CONSTITUTIONAL PRINCIPLE OF SEPARATION OF POWERS: THEORY AND PRACTICE OF IMPLEMENTATION}

The content and practice of the implementation of the constitutional principle of separation of powers are analyzed. The historical background of the concept of separation of powers is considered. Attention is drawn to the transformation of the classical content of the principle of separation of powers in modern conditions.

Key words and word-combinations: separation of powers, unity of state power, subsidiarity of powers, system of checks and balances, rule of law.
О.И. Цъгулиебская, доктор юридических наук, профессор, заведуюиий кафедрой теории права Поволжского института упраљления имени П.А. Стольтина - филиала Российской академии народного хозяйства и государстьенной служби при Президенте РФ, заслуженньй работник bьгсией икольг РФ (email: olga77.54@mail.ru)

T.B. МилушеВа, доктор юридических наук, заведующии кафедрой гражданского права и прочесса Поволжского института управления имени П.А. Стольтпна - филиала Российской академии народного хозяйства и государственной службь при Президенте РФ (email: mtv62@mail.ru)

\section{КОНСТИТУЦИОННЫЙ ПРИНЦИП РАЗАЕ ЕНИЯ ВААСТЕЙ: ТЕОРИЯ И ПРАКТИКА РЕААИЗАЦИИ}

\footnotetext{
Аннотация. Анализируются содержание и практика реализации конституционного принципа разделения властей. Рассматриваются исторические предпосылки формирования концепции разделения властей. Прослеживается трансформация классического содержания принципа разделения властей в течение времени.

Ключевые слова и словосочетания: разделение властей, единство государственной власти, субсидиарность властей, система сдержек и противовесов, правовое государство.

$\Pi$ оступательное Авижение к правовому государству актуализирует обсуждение «вечного» вопроса, значимость которого с течением времени не снижается, а возрас-
} 
тает, - илее разделения властей, которая получияа нормативное закрепление в российской Конституџии 1993 г. В постановлении Конституџионного СуАа РФ от 18 января 1996 г. № 2-П указано, что разделение властей закрепляется в Конституции РФ в качестве одной из основ конституционного строя Аця Российской Фелерации в целом, то есть не только для фелерального уровня, но и Аля организаџии государственной власти в ее субъектах [1] .

В условиях эйфории 1990-х годов разделение вмастей было безоговорочно воспринято как твердая гарантия демократического характера права, госуАарства, последствиями которого ожидалось установцение режима законности. ОАнако до сих пор теоретическая значимость и практическая роль разделения властей не осознана до конца ни российской политической элитой, ни обществом. Все это привело к тому, что в отечественной политической практике механизм разделения властей оказался практически невостребованным.

Председатель Конституционного СуАа РФ В. Зорыкин, размышляя о российской Конституции в преАдверии празАнования 25-летия ее принятия, обратил внимание на проблему дисбаланса ветвей власти, на усицение полномочий исполнительной ветви власти, недостаточную четкость в распределении полномочий межАу Президентом РФ и Правительством, в определении статуса ААминистрации Президента РФ и полномочий прокуратуры [2] .

Обозначенные проблемы вновь фокусируют внимание на теоретических и практических аспектах идеи разделения властей, исторически восходящей к Платону, Аристотелю, Аиодору Сиџилийскому, в трудах которых формировался фундамент просветительской философии Нового времени.

В классическом варианте учение о разделении властей сложилось в работах Аж. Аокка и Ш. Монтескье (XVII-XVIII вв.). Аж. Аокк, признавая бесспорное верховенство законодательной власти, наличие исполнительной власти обосновывал необходимостью контроцировать исполнение законов [3, c. 312]. Непременным условием функционирования исполнительной вцасти явцяется ее отделение от законодательной. По мнению Аж. Аокка, спещиацизация исполнительной власти способствует ее эффективности и делает ее безопасной, то есть неспособной использовать свою внешнюю мощь Аця Аавления на Аругие ветви вцасти. В исполнительную ветвь власти он вкцючал и власть судебную. Это связано, видимо, с тем, что Аля английской правовой системы судебная вмасть всегда быма достаточно самостоятельной, а авторитет суда в обществе традиционно высоким. Таким образом, уже к конџу XVII в. фундамент теории разделения вмастей бым в целом сформирован.

Аальнейшая ее модернизация связана с именем Ш.- . Монтескье, который высказал идею самоограничения вцасти, Аополниц конструкщию разделения властей системой сдержек и противовесов, обеспечивающей сбалансированность властей на основе закона. «В каждом государстве, констатировал философ, - есть три ряда власти: власть законодательная, власть исполнительная, ведающая вопросами международного права, и власть исполнительная, ведающая вопросами права гражданского. В силу первой власти государь или учреждение создает законы временные или постоянные и исправцяет ици отменяет существующие законы. В силу второй он объявцяет войну ици заключает мир, 
посылает и принимает послов, обеспечивает безопасность, предотвращает нашествие. В силу третьей власти он карает преступцения и разрешает столкновения частных $и ц$. Последнюю власть можно назвать судебной, а вторую просто исполнительной властью государства» [4, с. 209].

Основные положения Аанной концепџии нашли отражение в Аекларации независимости США, во французской Аекларации прав человека и гражданина, но наиболее полно она была реализована в Конституции США 1787 г. «Отцы-основатели» американской Конституции, опираясь на идеи Аж. ка и Ш.- . Монтескье, начаци так называемый «благородный эксперимент», который сводился к творческой практической реализаџии идей европейских мыслителей. Термин «благородный эксперимент» как нельзя мучше подчеркивал новаторский характер начинаний и в то же время - непрочность, шаткость государственно-правовой практики развивающегося американского государства [5, с. 152]. Аргументируя позиџию необходимости создания не идеацьного, утопического государственного устройства, а оптимацьного, Аж. Медисон писал о том, что «три ветви власти - разве только они связаны и слиты с тем, Аабы каждая осуществцяла конституџионный контроль наА двумя Аругими, - на практике не могут сохранять ту степень раздельности, которая, согласно аксиоме Монтескье, необходима свободному правлению» [6, c. 324]. Таким образом, следует согласиться с тем, что, сохраняя прежке всего не букву, а дух концепции Аокка - Монтескье, американские политики продемонстрировали возможность «вариаций» на тему, заданную английскими и французскими теоретиками.

Аамьнейшее развитие концепция разделения властей и их взаимного контроля получияа в идее разделять не только ветви власти, но и способы их формирования, то есть избирательную систему, подчинив ее принципу разделения властей. «Необходимо, чтобы все назначения на высшие Аолжности в исполнительных, законодательных и судебных органах исходили из первоисточника власти - от народа - и шли не по сообщающимся Аруг с Аругом канацам» [6, с. 346] .

Предвидев возможность усиления законодательной власти, американские мыслители высказывались за двухпалатную структуру законодательного органа. «Выборный деспотизм, - писац Т. Ажефферсон, - отнюдь не та форма правления, за которую мы сражацись».

Отечественные юристы И.В. Гессен, М.М. Ковалевский, В.С. Соловьев, П.Б. Струве, С.А. Муромцев, Б.Н. Чичерин, развивая идеи западного Просвещения, считаци, что механизм разделения вцастей явцяется еАинственным среАством Аля предотвращения револющии в России.

Марксисты отрицали принцип разделения властей и в качестве антипода выдвигали идею "разделения труда» по реализации единой государственной власти. Это наглядно продемонстрировала политическая практика Советского государства, которое ни юридически, ни фактически не воспринимало Аанный принцип, он существовац формально, на практике все ветви власти подчинямись партийной гегемонии.

В ходе многочисленных острых Аискуссий относительно теории разделения 
властей выработаны конкретные универсальные положкения, составляющие основу рассматриваемой теории. Конџепџию раздемения властей, как преАставляется, можно рассматривать в качестве «общего» Аля всех ее вариантов, независимо от того, где, в какой стране и при каком политическом режиме она применяется и как интерпретируется. Среди такого рода достаточно устоявшихся универсальных положений можно выделить следующие постулаты:

- теория разделения властей представляет собой раздемение государственной власти на законодательную, исполнительную и судебную;

- в каждой стране, именующей себя демократической, законодательная, исполнительная и судебная власти не только тесно связаны межАу собой единым государственным механизмом, но и относительно самостоятельны;

- межАу высшими государственными органами, осуществмяющими законодательные, исполнительные и судебные функции, существует некий баланс властей, действует система сдержек и противовесов;

- все три власти действуют, как правило, на постоянной правовой основе. Поскольку законы, как писал Аж. Аокк, «обладают постоянной и устойчивой силой и нуждаются в непрерывном исполнении ици наблюдением за этим исполнением, то необходимо, чтобы все время существовала власть, которая следима бы за их исполнением [3, с. 347];

- степень и характерные особенности процесса реализации разделения властей обусловлены конкретными факторами (формой правления, формой территориального устройства, характером политического режима, историческими, национальными и политическим традициями).

Аля эффективной работы механизма вмаствования в государстве необходимы некоторые условия: относительная независимость и самостоятельность ветвей власти; взаимное сотрудничество; работаюшая сбалансированная система сдержек и противовесов. Будучи совокупностью взаимосвязанных элементов, обеспечивающих в рамках закона эффективное взаимодействие ветвей власти, она играет роль «живых тканей, сосудов государственного механизма» [7, с. 2] .

Эволюция современного государства содержательно обогатила идею разделения властей, наполняет ее новым содержанием, поскольку условия жизнедеятельности государства и общества существенно трансформировали. Сторонники баланса ветвей власти, анализируя механизм раздемения властей, все больше обращают внимание на следующую тенденцию. Ученые-правоведы (да и представители всех отраслей обществоведения) отмечают, что фактически представительные и судебные учреждения постепенно превращаются из равнозначных и равноправных оппонентов исполнительной власти в инстанџии, более или менее эффективно сдерживающие и контролирующие последнюю [8, с. 150]. И это естественно, ибо «усиление» исполнительной власти есть объективная реальность, обусловленная главным образом усложнением процессов общественного развития. В то же время существует опасность неукмонно продолжаюшегося усиления исполнительно-распорядительных органов, которая сегодня все яснее осознается как обществом, так и преАставителями властных структур.

Аоминирующее положкение исполнительной власти в системе разделения 
властей обусловлено управленческим характером деятельности, которую она осуществляет: предвидением, прогнозированием, планированием, принятием необходимого решения, мобилизаџией и организаџией сил и ресурсов, контроль выполнения и многим Аругим. Учитывая сложившиеся реалии, преАставительная и судебная власти призваны осуществлять сдерживающие и контролирующие усилия по отношению к власти исполнительной, не Аопуская концентрации государственной власти в руках профессиональных управленцев.

В последнее время в науке появились новые подходы к модели организации власти в России, учитывающие ее федеративное строение. В частности, принципы единства и разделения властей Аополняются положением о субсидиарности властей [9, с. 75]. Отношения субсидиарности складываются межАу разАичными уровнями феАеративной системы власти.

Современные отечественные и зарубежкные ученые утвержкаюют, что клю-

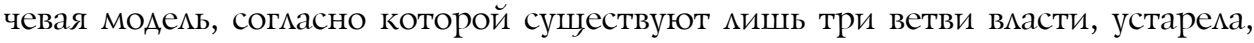
не соответствует современным реалиям [10, с. 396-401]. Так, во многих Аемократических государствах функционируют институты, которые не вписываются ни в одну из традиционных ветвей власти. В России к таковым относятся Центробанк РФ, ААминистраџия Президента РФ, Счетная палата РФ и Аругие. В связи с этим высказываются позиции о необходимости выделять контроцьную ветвь вцасти [11, 346-352], избирательную вцасть [12; 13] . Существующую триаду ветвей власти предлагается расширить за счет новых и переименованных традиционных понятий: правящая власть, законодательная вмасть, аАминистративная власть, судебная власть, судебная конституционная власть $[14$, с. 42]. Е.В. Коврякова указывает на множественность ветвей вмасти: законодательную, исполнительную, судебную, учредительную, избирательную, контрольную, гражданскую, организационную, президентскую, народную, прокурорскую, финансово-банковскую, надзорную, Аенежную [15, с. 67] . Справедииво мнение и о том, что сегодня исполнительную вцасть точнее называть властью «управцяющей». Именно она является основным разработчиком правовой политики, идей, конџепџий, которые впослеАствии преАставляются на одобрение парламенту [16, с. 80] .

В практике реализации разделения вмастей в России прежде всего отмечается существенный изъян формулировки ст. 10 Конституции РФ, регламентирующей, что «государственная власть осуществцяется на основе ее разделения на законодательную, исполнительную и судебную ветви. Органы законодательной, исполнительной и судебной власти самостоятельны». В таком изложении статья Аопускает неоднозначное толкование соотношения ветвей вмасти, при этом акџентируется внимание на их обособлении. Между тем С.А. Авакъян подчеркивает, что Конституџия России не Аает оснований говорить о «вмастях», у нас их не множество, а одна - единая вцасть народа (ст. 3 Конституции РФ), то есть термин «разделение власти» точнее, чем «разделение вмастей» $[17$, с. 15]. Очевидно, что раздемение властей Аолжно вытекать из принџипа единства государственной вцасти, обусловленного еАиной политико-экономической основой деятельности государства; общности целей и задач, выполняемых государственными структурами; нацичия общих принципов построения 
и функционирования государственных органов. С учетом принципа «единства раздеменных властей» следует скорректировать и ст. 10 Конституции РФ, изможив ее следующим образом: «Государственная власть осуществляется на основе ее разделения на законодательную, исполнительную и судебную ветви. Органы законодательной, исполнительной и судебной власти самостоятельны “в пределах своих полномочий”».

Весьма широки полномочия Президента РФ, который формирует и контролирует деятельность Правительства РФ, а также системы исполнительной власти в целом. Президенту прямо подчинены и подотчетны ряд федеральных органов исполнительной власти. Он определяет основные направцения внутренней и внешней политики государства, осуществмяет руководство внешней политикой, ведет переговоры, подписывает межАународные договоры и многое Аругое. По обширному кругу его полномочий он фактически находится над тремя ветвями власти. Президент РФ, президентская Администрация и Правительство РФ - высшая государственная бюрократия, реальная политическая сила, определяющая на практике тон всех государственно-правовых преобразований в современной России $[18$, с. 20-21]. Таким образом, модель организаџии российской власти строится на следующих началах: суперсильный статус Президента; юридически и фактически смешенный баманс ветвей власти в сторону ее исполнительной ветви; пассивный парламент, создающий угрозу потери демократических свобод, Аоставшихся россиянам векикой ценой.

Резюмируя изложенное, подчеркнем, что разделение властей - важнейшее условие и основной механизм функционирования государственной власти, он является основой государственного строительства в высокоразвитых странах современного мирового сообщества. Практическая ценность этого института власти состоит в установлении мощных конституџионных гарантий против тенденции к полновластию одной из ее ветвей.

Разделение властей (распределение полномочий по осуществлению госуАарственной власти межАу независимыми друг от Аруга органами) вытекает из принщипа правового государства. Существование правового государства невозможно без системы раздемения властей, где власть судебная выступает гарантом соблюдения права самим законодатемем и правоприменителем, где конституџионное судопроизводство является необходимой частью государственного механизма, позволяющего реально воздействовать на функџионирование самостоятельных законодательной, исполнительной и судебной властей. Вместе с тем понятие «разделение властей», содержит в своем объеме определенную долю условности и требует уточнения в кажАом конкретном случае. Обратная сторона конституционного раздемения вмастей - положение о единстве государственной власти, органически вытекающего из природы государственной власти, которая не может быть ни соџиально, ни юридически разделена на части [19, с. 259].

Система государственной вмасти как устойчивая эвомющионирующая поАсистема должна характеризоваться как целевым, так и функциональным единством. Ааже в абстракции невозможно разделить функции власти, реа- 
мизуемой в непрерывном потоке решений и действий. При нормальном взаимодействии и коопераџии властей нет граниџ разделению труда. Именно поэтому реализаџия принџипа разделения властей Аолжна быть обеспечена эффективным механизмом правового регулирования, в котором особое место отводится взаимодействию властей, полномочиям, ответственности.

Принцип разделения властей имеет не абсолютный, а относительный характер и модифицируется в зависимости от конкретных исторических, политических и иных реаций. Это в полной мере относится и к России, которая развивает модель разделения властей, отвечающую ее современным потребностям.

\section{Библиографический список}

1. По делу о проверке конституционности ряда положений Устава (Основного Закона) Алтайского края: постановление Конституционного Суда РФ от 18 янв.1996 г. № 2-П // Российская газета. 1996. № 20.

2. Зорькин В. Буква и дух Конституции // Российская газета. 2018. 10 окт.

3. Локк Дж. Соч.: в 3 т. М., 1991. Т. 3.

4. Монтескье Ш. О духе законов // Монтескье Ш. Избранные произведения: в 2 т. / под общ. ред. М.П. Баскина. М., 1955.

5. Теория государства и права: учебное пособие: в 2 ч. Таганрог, 2008. Ч. 1.

6. Федералист. Политическое эссе Гамильтона А. Медисона, Дж. и Джея Дж. М., 1993.

7. Лузин В.В. Президентская модель разделения властей (на примере США) // Государство и право. 1999. № 3. 2014.

8. Керимов А.Д. Государственная организация общественной жизни: вопросы теории. М.,

9. Чиркин В.Е. Сравнительное государствоведение: учебное пособие. М., 2011.

10. Авакьян С.А. Конституционное право России: в 2 т. 4-е изд. М., 2017. Т. 1.

11. Чиркин В.Е. Государствоведение. М., 2000.

12. Конституция Никарагуа 1987 г. URL: https://worldconstitutions.ru/?p=52\&attempt=1

13. Конституция Бразилии 1988 г. URL: http://brasil-russia.ru/wp-content/uploads/2014/01/\%.pdf

14. Романенко В.Б. Новая модель разделения властей в социальном правовом государстве // Научная мысль Кавказа. 2011. № 1.

15. Коврякова E.B. Адогматический характер теории разделения властей // Lex russica. 2015. № 5 .

16. Ижуткина И.В. Разделение властей как основа взаимодействия органов власти // Проблемы государственного строительства и права / под общ. ред. Г.В. Мальцева / отв. ред. С.В. Бошно. M., 2001.

17. Авакьян C.A. Разделение властей: до каких уровней применять? // Вестник Саратовской государственной юридический академии. 2018. № 4 (123).

18. Комутков C.B. От единовластия к разделению властей // Власть. 2005. № 1.

19. Чиркин B.E. Конституционное право: Россия и зарубежный опыт. М., 1998. 